\title{
Immune Dysfunction and the Pathogenesis of AIDS- associated non-Hodgkin's Lymphoma
}

\section{Otoniel Martínez-Maza ${ }^{+}$, Daniel Widney, Meta van der Meijden, Reba Knox, Angela Echeverri, Elizabeth C Breen, Larry Magpantay, Steven A Miles}

\begin{abstract}
Departments of Microbiology, Immunology \& Molecular Genetics, Medicine, and Obstetrics \& Gynecology and Jonsson Comprehensive Cancer Center, UCLA School of Medicine, Los Angeles, CA 90095-1747, USA

Much has been learned about how HIV-induced immune dysfunction contributes to B cell hyperactivation, and potentially, to the pathogenesis of AIDS-lymphoma. However, further studies are needed to fully understand how HIV infection and immune dysfunction promote B cell hyperactivation and the development/growth of AIDS-lymphoma. In particular, studies are needed to define the role of HHV8 vIL6, IL6 receptor-expression, and lymphocyte surface stimulatory molecules, in promoting $B$ cell hyperactivation or lymphoma cell growth.
\end{abstract}

Key words: B lymphocytes - HIV - AIDS - lymphoma - interleukin 6 - HHV8

The risk of developing lymphoma is greatly increased in people who have HIV infection: approximately $10 \%$ of people with AIDS develop non-Hodgkin's lymphoma (AIDS-lymphoma) (Ziegler 1987, Rosenberg \& Fauci 1990, Pluda et al. 1990, Gail et al. 1991, Moore et al. 1991, Beral et al. 1991, Karp \& Broder 1991, Martínez-Maza 1993, Ballerini et al. 1993, Knowles 1997). Also, it is clear that the incidence of AIDS-lymphoma has been increasing. For instance, within the participants in the Multicenter AIDS Cohort Study (MACS), AIDS-lymphoma incidence has increased from <2 cases/1000 person years in 1986 to $>12$ in 1995, and AIDS-lymphoma as the initial presenting AIDS diagnosis within this cohort has risen from $2.1 \%$ in $1985-87$ to $9.9 \%$ in $1995-96$ (unpublished results). The overall aim of our studies has been to determine how HIV infection-associated immune dysfunction contributes to the development and/or growth of AIDS-lymphoma.

AIDS-lymphoma: pathology and molecular lesions - AIDS-lymphomas can be segregated into several categories: Burkitt's lymphoma-like small noncleaved cell lymphoma (SNCCL), large cell immunoblastic plasmacytoid lymphoma (IBL), large non-cleaved cell lymphoma (LNCCL), and primary effusion lymphoma (PEL), also known as

\footnotetext{
This work was supported by grants from the NIH (US) (CA57152, CA73475, AI36086, AI35040) and the California Universitywide AIDS Research Program (R95LA-105).

${ }^{+}$Corresponding author. Fax: +1-310-206.3670

Received 11 March 1998

Accepted 16 April 1998
}

body-cavity lymphoma, a relatively rare form of AIDS-lymphoma (Cesarman et al. 1995, Knowles 1997). These four types of AIDS-lymphoma differ in the frequency of c-myc:immunoglobulin (Ig) gene chromosomal translocations, in anatomical distribution (most primary CNS AIDS-lymphomas are IBL), and in Epstein-Barr virus (EBV) positivity (MacMahon et al. 1991, Knowles 1997). All SNCCL display c-myc:Ig translocations. However, only about one-third of these SNCCL are EBVpositive (Ballerini et al. 1993). All IBL, on the other hand, are EBV-positive, but only a fourth of these have c-myc:Ig translocations. An intermediate pattern is seen in LNCCL: $25 \%$ are EBV-positive and $50 \%$ had a c-myc:Ig translocation. Also, LNCCL have been seen to be associated with the translocation and overexpression of the $b c l-6$ protooncogene (Gaidano et al. 1997). Therefore, although virtually all AIDS-lymphomas are B cell tumors, these tumors are heterogeneous, in histological type, clinical behavior, and in the molecular lesions associated with these histologically-defined categories. This suggests that more than one pathogenetic mechanism contributes to the development and progression of AIDS-lymphoma (Klein 1989, Knowles 1997).

Role of B cell hyperactivation in the pathogenesis of AIDS-lymphoma - While HIV infection is characterized by a decrease in the function/number of CD4 T cells, a marked increase in B cell activation also is seen, as evidenced by elevated serum immunoglobulin [Ig] and spontaneous Ig secretion, and increased numbers of circulating activated B cells (Lane et al. 1983, Lane \& Fauci 1985, Martínez-Maza et al. 1987, Mizuma et al. 1988, Edelman \& Zolla-Pasner 1989, Rosenberg $\&$ Fauci 1990, Widney et al. 1994). This chronic 
B cell hyperactivation precedes, and probably contributes to lymphomagenesis in HIV infection (Martínez-Maza 1993, Przybylski et al. 1996). This chronic in vivo B cell hyperactivation could contribute to lymphomagenesis simply by increasing the size of the target cell population at risk for genetic accidents that contribute to lymphomagenesis, such as the c-myc:Ig gene chromosomal translocation (Klein 1989). However, it is possible that specific features of this B cell hyperactivation are especially important in the pathogenesis of AIDSlymphoma.

One form of B cell hyperactivation that has the potential to be uniquely associated with the development of non-Hodgkin's lymphoma is increased Ig isotype switching. Ig isotype switching is a normal feature of humoral immune responses: primary immune responses are characterized by the production of the IgM class (m isotype), while secondary immune responses to the same antigen feature a much greater proportion of other Ig classes, particularly $\operatorname{IgG}$ ( $g$ isotype). This switch in $\mathrm{Ig}$ isotype, or heavy-chain, to $\operatorname{IgG}, \operatorname{IgA}$ or $\operatorname{IgE}$, involves a DNA rearrangement in the Ig heavy chain gene. When isotype switching is signaled by various B cell stimulatory factors, including cytokines (IL4, IL13, IL10) and cell surface stimulatory molecules (CD40:CD40 ligand, sCD23), the rearranged DNA joins at the switch regions (discrete regions 5 ' to the heavy chain coding sequences), with the subsequent excision of intervening heavychain sequences, allowing the Ig variable region gene segment to be placed close to the coding region for the new Ig heavy-chain isotype. Some cytokines induce Ig isotype switching targeted to certain Ig isotypes: IL4 and IL13 preferentially induce switching to IgE and IgG4. Other cytokines, such as IL10 and IL6, enhance Ig class switching without preference for Ig class (Burdin et al. 1997).

The induction of Ig isotype switching may enhance the occurrence of c-myc:Ig translocations, since this translocation is thought to result from an error in the DNA rearrangements that take place during isotype switching (Potter 1992, Macgrath 1992). Rearrangement of the c-myc oncogene is seen in both sporadic (North American and European) and endemic (African) Burkitt's lymphoma, as well as in many AIDS-lymphomas (Neri et al. 1988, Subar et al. 1988, Klein 1989, Karp \& Broder 1991, MacMahon et al. 1991, Potter 1992, Macgrath 1992, Martínez-Maza 1993, Ballerini et al. 1993, Cesarman et al. 1995, Schulz et al. 1996, Knowles 1997, Gaidano et al. 1997). The rearrangement seen in AIDS-lymphoma involves the c-myc gene (often truncated) and the switch region of the Ig heavy-chain gene (Lombardi et al. 1987, Subar et al. 1988, Neri et al. 1988, Potter 1992,
Macgrath 1992, Ballerini et al. 1993, Schulz et al. 1996). While lymphoma results from the accumulation of several genetic lesions, which together result in dysregulated growth and an increased clonal life span, the c-myc:Ig translocation is of great pathogenetic importance, since this translocation can result in a perpetually proliferative state (Lombardi et al. 1987, Shiramizu \& Macgrath 1990, Macgrath 1992).

Ig isotype switching is driven by various $\mathrm{B}$ cell stimulatory factors, including cytokines (IL4, IL13) and other $\mathrm{B}$ cell-stimulatory molecules (CD40:CD40 ligand, sCD23). Since HIV infection-associated $\mathrm{B}$ cell hyperstimulation, in particular the chronic stimulation of B cells to undergo isotype switching, may play an important role in the pathogenesis of AIDS-lymphoma, and since sCD23 is associated with Ig isotype switching, we examined serum sCD23 levels in a study of HIVpositive subjects who had developed AIDS-lymphoma. Subjects were participants in the UCLAMACS, and were segregated into four groups: (1) AIDS-lymphoma, (2) AIDS, with no history of an AIDS-related malignancy, (3) HIV+ with no AIDS-defining conditions, and (4) HIV seronegative. sCD23 and IgE levels were measured in all available sera from visits in the 18 months prior to the diagnosis of AIDS-lymphoma. Greatly elevated sCD23 serum levels were seen in those who developed AIDS lymphoma, when compared to others with AIDS (without lymphoma), or to HIVseronegative or HIV+ subjects who did not have AIDS (Yawetz et al. 1995). Since the induction of IgE has been tied to the activity of CD23, serum IgE levels also were examined, and found to be significantly elevated in those that developed AIDS lymphoma (Yawetz et al. 1995). Recently, this finding was confirmed by others (Zinzani et al. 1996), who noted that $\mathrm{sCD} 23$ may be a specific prognostic parameter for non-Hodgkin's lymphoma.

Also, in recent work, we noted that another molecule associated with $\mathrm{B}$ cell hyperactivation, soluble CD27 (sCD27) is elevated prior to the appearance of AIDS-lymphoma (unpublished observation). Cell surface CD27, a lymphocyte activation antigen, can be proteolytically cleaved to produce sCD27, which has been seen to be elevated in a number of disease states and malignancies. Serum sCD27 levels in HIV infection and in AIDSassociated lymphoma were measured in a study similar to that described above for sCD23. Significantly elevated levels of sCD27 were seen in subjects who developed AIDS-lymphoma, when compared to subjects with AIDS (non-lymphoma), or to HIV+ (non-AIDS) or HIV-negative subjects (unpublished observation). Both AIDS (non-lymphoma) and HIV-positive (non-AIDS) groups also 
had significantly elevated serum sCD27 levels, when compared to HIV-negative controls. AIDSlymphoma cell lines also were seen to express cell surface CD27 and its ligand, CD70, and to produce substantial amounts of sCD27. Furthermore, a majority of primary AIDS-lymphoma specimens expressed both CD27 and its ligand, CD70.

Together, these results suggest that $\mathrm{B}$ cell hyperactivation, resulting in $\mathrm{CD} 23, \mathrm{IgE}$, and CD27 overproduction, occurs in HIV infection. Furthermore, the observation that serum sCD27 and sCD23 levels are elevated prior to the development of AIDS-lymphoma, suggests that serum levels of these molecules may have prognostic value in predicting the development of AIDS-lymphoma. More recently, we have re-examined sCD23 expression prior to AIDS-lymphoma, using a more specific second-generation ELISA for sCD23 (Binding Site), and examining a much larger number ( $n \sim 50)$ of subjects with AIDS-lymphoma, using a similar study design to that described above. In addition to $\mathrm{SCD} 23, \mathrm{SCD} 27, \mathrm{IgE}, \mathrm{IL6}$, and IgG4 expression were measured simultaneously in sera from these subjects. Preliminary assessment of these results confirms that $\mathrm{sCD} 23$ is elevated, prior to AIDS-lymphoma, particularly in subjects who developed Burkitt's/SNCCL (unpublished observations). Interestingly, serum IL6 levels also were seen to be elevated, over levels seen in subjects with AIDS but without lymphoma, only in subjects who developed Burkitt's/SNCCL AIDS-lymphoma, a type of lymphoma that is characterized by c-myc:Ig translocations (MacMahon et al. 1991, Ballerini et al. 1993, Knowles 1997), but not in those who developed IBL, large cell, or CNS lymphoma.

EBV infection also may contribute to B cell hyperactivity in people with HIV infection, as well as directly to the genesis of AIDS-lymphoma. EBV can immortalize infected human B cells. Some types of AIDS-lymphoma (IBL) may represent EBV-transformed B cells growing in an uncontrolled fashion in an environment devoid of functional immunoregulation. The high frequency of EBV infection, and low frequency of c-myc:Ig gene translocations, seen in IBL and in CNS lymphomas (Ballerini et al. 1993, Knowles 1997), supports this notion, as does the fact that IBL and CNS lymphomas occur in people with low numbers of CD4 T cells (Muñoz et al. 1993). While widely prevalent, EBV infection is normally tightly controlled by $\mathrm{T}$ cell-mediated immunoregulation, including cytotoxic T cells (CTL) (Tosato \& Blaese 1985). However, these EBV-immunoregulatory mechanisms are known to be deficient in people with AIDS (Birx et al. 1986).

While chronic B cell hyperactivation and loss of immunoregulatory mechanisms almost certainly contribute to the initial development of AIDS-lymphoma, immune dysfunction also may contribute to the continuing growth of malignant lymphoma cells. Various B cell-stimulatory factors could directly support the growth of emerging malignant AIDS-lymphoma cells, by serving as autocrine/ paracrine growth or viability factors. For example, IL6, a B cell-stimulatory cytokine that has been seen to act as a growth factor for various human malignancies, including multiple myeloma, as well as IL10, also a B cell-stimulatory cytokine, are produced by or near AIDS-lymphoma cells in vivo (Emilie et al. 1992a, b, 1997). We have seen that IL6 can enhance the resistance of EBV-transformed lymphoblastoid B cell lines (B-LCL), cells that are similar to IBL cells, to specific CTL (Liu et al. 1995). Our recent preliminary studies indicate that IL6 is elevated prior to the appearance of AIDSlymphoma, particularly in those who develop Burkitt's, SNCCL AIDS-lymphoma. Therefore, immune dysfunction, in particular the over-production of B cell-stimulatory cytokines, could contribute to the growth of nascent lymphoma cells, in addition to contributing to the genesis of these cancers.

Immune dysfunction and B cell hyperactivation in HIV infection - There are several means by which HIV infection could result in polyclonal B cell activation: (1) direct polyclonal activation of B cells by HIV or HIV superantigens (Pahwa et al. 1985, 1986, Schnittman et al. 1986, Yarchoan et al. 1986, Berberian et al. 1993), (2) chronic antigenic stimulation of B cells by HIV (Amadori et al. 1989), (3) HIV infection resulting in the loss of $\mathrm{T}$ cell-mediated immunoregulation of EBV-positive B cells (Birx et al. 1986, Martinez-Maza 1993), (4) HIV-induced over-production of IL6 and other B cell stimulatory cytokines (Rosenberg \& Fauci 1990, Breen et al. 1990, Birx et al. 1990, Amadori et al. 1991, Rieckmann et al. 1991, Honda et al. 1991, Martínez-Maza 1992, 1993, Macchia et al. 1993), and (5) the inappropriate expression of noncognate T/B cell stimulatory molecules (Macchia et al. 1991, 1993, Chirmule et al. 1993). While the relative contribution of these different mechanisms to B cell hyperactivation in HIV infection has not been defined, some information is available that allows the contributions of these different mechanisms to the induction of $\mathrm{B}$ cell hyperactivation to be judged. Chronic antigenic stimulation by HIV cannot be primarily responsible for HIV infection-associated B cell hyperactivation, since a majority of the activated B cell clones seen in HIV-infected subjects are not reactive with HIV antigens (Amadori et al. 1989). $\mathrm{V}_{\mathrm{H}} 3$ Ig molecules appear to be natural ligands for 
gp120, and $\mathrm{V}_{\mathrm{H}} 3+\mathrm{B}$ cells are activated by gp120 (Berberian et al. 1993): this $\mathrm{V}_{\mathrm{H}} 3$-gp120 superantigen interaction may be responsible for some of the B cell hyperactivation seen in HIV infection. However, this alone cannot account for this phenomenon, since the $\mathrm{V}_{\mathrm{H}} 3 \mathrm{~B}$ cell subset was seen to be completely deleted in people with AIDS and advanced HIV disease (Berbarian et al. 1991), when B cell hyperstimulation is most marked (Mizuma et al. 1988, Vincent et al. 1992). Therefore, at the point in the course of HIV disease when $B$ cell hyperactivation is maximal, impaired immunoregulation of EBV+ B cells (Tosato \& Blaese 1985, Birx et al. 1986), and/or cytokine and stimulatory molecule over-production, most probably play the dominant role in inducing B cell hyperactivation.

$B$ cell hyperactivation in HIV infection: role of IL6, a B cell-stimulatory cytokine - There is significant evidence that the over-production of IL6, a cytokine that induces B cells to become Igsecreting cells (Hirano et al. 1987, 1990, Matsuda et al. 1989), can contribute to B cell hyperactivation in HIV infection. In the past, we have devoted much of our attention to elucidating the role of IL6 in AIDS pathogenesis, working in collaboration with Tadamitsu Kishimoto. We were the first to report that exposure of human monocytes to HIV leads to IL6 gene expression and secretion (Nakajima et al. 1989), and that elevated levels of IL6 and C'-reactive protein (CRP, an acute-phase reactant induced by IL6) are seen in HIV-infection (Breen et al. 1990), work that has been confirmed by others (Birx et al. 1990, Honda et al. 1991, Lafeuillade et al. 1991, Rautonen et al. 1991, de Wit et al. 1991, Clouse et al. 1991). In subsequent studies, we found that gp41 is the HIV-encoded product responsible for inducing IL6 production by monocytes (Takeshida et al. 1995). Also, we have seen that IL6 levels are highest in advanced HIV disease, when B cell hyperactivation is most apparent (unpublished observation). Recently, it was seen by others that treatment of HIVinfected subjects with antibodies to IL6 resulted in a marked decrease in B cell hyperactivation (Marfaing-Koka et al. 1996).

More recently, we found significantly elevated levels of IL6 receptor (IL6Ra'CD126') expression on B cells (CD19+ cells) and monocytes (CD14+) in HIV infection, with the level of IL6Ra expression being highest in those subjects who had high plasma HIV RNA levels (unpublished observation). The IL6 receptor complex is made up of gp130'CD130', a $130 \mathrm{kDa}$ signal-transducing subunit, and IL6Ra'CD126', an $80 \mathrm{kDa}$ cytokinebinding subunit (IL6Ra) (Greaing et al. 1992, Kishimoto et al. 1994, 1995). The response to
huIL6 is controlled by the expression of IL6Ra: cells that do not express this receptor subunit do not respond to huIL6 (Hirano et al. 1990, Kishimoto et al. 1994, 1995). While gp130 is widely expressed, IL6Ra expression is regulated closely and controls responsiveness to IL6: activated, IL6-responsive B cells display marked IL6Ra expression, while resting B cells do not (Kishimoto et al. 1994, 1995). Since IL6Ra expression determines IL6 responsiveness, and the altered expression of this molecule could contribute to immune dysfunction, we examined IL6Ra expression in HIV infection. An elevated number of IL6Ra-positive B cells and monocytes was seen in HIV infection (unpublished observation). These increases did not correlate with CD4 levels. However, preliminary studies suggest that elevated IL6Ra expression correlates with HIV plasma RNA levels (unpublished observation). Also, preliminary studies indicate that exposure of cells that have elevated IL6Ra expression to recombinant huIL6 usually resulted in increased STAT3 phosphorylation (unpublished observation). Unexpectedly, cells from some subjects who had high levels of IL6Ra expression did not display correspondingly increased STAT3 phosphorylation following huIL6 exposure. This suggests that down-regulatory mechanisms, such as the up-regulation of the recently described STAT-induced STAT inhibitors (SSI) (Naka et al. 1997, Starr et al. 1997, Endo et al. 1997, Minamoto et al. 1997), may occur in cells that express elevated levels of IL6Ra. Together, these findings suggest that IL6 over-production, and perhaps the enhanced responsiveness to IL6 due to the over-expression of IL6Ra, play an important role in B cell hyperstimulation in HIV infection.

The HHV8-encoded IL6 homologue, vIL6, is a potential contributor to $B$ cell hyperactivation in HIV infected people - HHV8 is a human g-herpesvirus (also called KSHV: KS-associated herpesvirus), originally found in AIDS-associated Kaposi's Sarcoma (AIDS-KS) lesions (Chang et al. 1994). While HHV8 was initially identified from sequences seen in KS lesions, infection with this virus is not restricted to such cells, or to people with KS. In fact, HHV8 infection has been seen to occur widely in people with HIV infection, and appears to occur, albeit less frequently, in people who are not HIV infected (Lennette et al. 1996, Knowles \& Cesarman 1997, Blackbourn et al. 1997). Although HHV8 infection seems to be associated with KS, the role of HHV8 infection in the pathogenesis of KS remains unclear. Also, it is not clear whether the near universal HHV8 seropositivity seen in subjects with KS represents a new/recent infection, or the reactivation of a pre- 
vious infection with this herpesvirus. Certainly, other human g-herpesviruses, such as EBV, have a high prevalence of infection in human populations, with initial infection resulting in a life-long, low level of infection, which is tightly-regulated by immunoregulatory mechanisms (Tosato \& Blaese 1985).

HHV8, like EBV, appears to be tropic primarily for human B cells (Knowles \& Cesarman 1997, Blackbourn et al. 1997). However, the great majority of AIDS-lymphomas are not infected with HHV8 (Cesarman et al. 1995, Knowles \& Cesarman 1997), the exception being a rare type of AIDS-lymphoma, PEL, which are HHV8-positive (Cesarman et al. 1995). Therefore, even though HHV8 can infect human B cells, the direct infection and transformation of B cells by HHV8 does not seem to play a significant role in the pathogenesis of the types of lymphomas seen most commonly in people with HIV infection, in contrast to the role of EBV infection in IBL and CNS AIDSlymphomas (Knowles 1997).

In spite of this, HHV8 infection might play an indirect role in the pathogenesis of AIDS-lymphoma, by producing a virus-encoded version of IL6, a potent B cell-stimulatory cytokine. Recently, various groups identified an HHV8 gene encoding a homologue of human IL6 (huIL6) (Moore et al. 1996, Nicholas et al. 1997, Neipel et al. 1997). Shortly after this, the entire sequence of HHV8 was identified, and the HHV8 K2 gene was seen to encode vIL6 (Russo et al. 1996). While vIL6 has somewhat limited (25\%) amino acid sequence identity to huIL6, $22 \%$ of the non-identical residues represent conservative amino acid substitutions, and vIL6 appears to have a very similar secondary structure to huIL6, with four major a-helical segments and a signal sequence. vIL6 does appear to be biological active: vIL6 expressed in transfected eukaryotic cells was seen to induce the proliferation of huIL6-responsive murine cell lines (Moore et al. 1996, Nicholas et al. 1997) and can induce the phosphorylation of STAT proteins in an huIL6responsive hepatocyte cell line (Molden et al. 1997). Interestingly, vIL6-signaling, mediated through gp130 on hepatocyte cells, was seen to occur in the absence of the IL6Ra subunit of the IL6 receptor, in contrast to huIL6 signaling, which requires the IL6Ra receptor element (Molden et al. 1997). The biological effects of vIL6 on human B cells have not been defined.

Since HHV8 infection is seen commonly in people with HIV infection and vIL6 can mimic the biological effects of huIL6, and since huIL6 is thought to contribute to B cell hyperactivation in HIV infection, it is important to define the biological effects of vIL6 on human B cells. Very re- cently, we initiated preliminary work to allow us to examine the biological effects of vIL6, and vIL6 receptor utilization, on human $\mathrm{B}$ cells. In these preliminary studies, we have cloned and sequenced vIL6, produced several specific anti-vIL6 sera, have expressed recombinant vIL6, and have seen that recombinant vIL6 (either expressed in E. coli or in transfected HeLa cells) has biological activity in a bioassay based on the proliferation of the huIL6-responsive MH60.BSF2 B cell line (Breen et al. 1990). In the future, we hope to delineate vIL6 receptor utilization and signaling pathways in human B lymphocytes, and to define the biological effects of vIL6 on human B lymphocytes.

$B$ cell hyperactivation in HIV infection: potential role of cell-surface immune-stimulatory molecules - While the over-production of human and/or viral IL6 and other cytokines may be of great importance in the induction of B cell hyperstimulation seen in HIV infection, other factors must be involved, since several signals are necessary for the induction of B cell activation. In fact, the process of B cell activation involves an on-going "dialogue" between T cells and B cells, much of which is mediated by non-cognate, cell contact-mediated signaling via pairs of cell surface molecules (Schevach 1993, Parker 1993). Of particular interest are the B/T cell-ligand pairs of CD40:CD40 ligand, CD27:CD70, and B7.1'CD80'/B7.2' CD86':CD28. CD40-ligand, unlike CD28, is not expressed on resting $\mathrm{T}$ cells but is up-regulated following activation (Noelle et al. 1992, Schevach 1993, Parker 1993, Roy et al. 1993, Armitage et al. 1993, Alderson et al. 1993). Conversely, while CD40 is constitutively expressed on B cells, B7.1 and B7.2 expression is normally seen on activated B cells (Schevach 1993, Parker 1993). On initiation of cellular activation, the coordinated up-regulated expression of these molecules allows their interaction, driving further activation. While the over-expression of these cell-surface activation molecules has the potential to contribute to B cell hyperactivation in HIV infection, little is known about how these stimulatory molecules contribute to B cell hyperactivation, or to the development or growth of AIDS-lymphoma cells.

Recent preliminary studies have focused on the expression of cell-surface stimulatory molecules on B cells, as well as CD4 and CD8 T cells, in HIV infection. Elevated levels of expression of the following molecules were seen on B cells in people with HIV infection: CD40-ligand, fas' CD95', CD23, B7.2'CD86', and CD28 (unpublished observations). CD40-ligand and CD28 are cell-surface stimulatory molecules, normally expressed on activated $T$ cells, but not on circulating $B$ cells. It interesting to note that increased $B$ cell 
expression of CD40-ligand was seen in people with advanced HIV disease, the same subjects that have the highest level of $\mathrm{B}$ cell hyperactivation and AIDS-lymphoma. Levels of B cell expression of CD40 (expressed on $~ 90 \%$ of cells) were unchanged, and levels of expression of CD27, CD70, CD30, B7.1'CD80', and TNF-R were decreased in HIV infection.

Since HIV infection-associated B cell hyperactivation is most marked when CD4 levels are low, we initiated studies to determine if CD8 T cells expressed immune stimulatory molecules normally expressed on CD4 helper T cells. This work was motivated by evidence that $\mathrm{CD} 8 \mathrm{~T}$ cell clones isolated from HIV+ subjects could exert helper T cell activities (Erard et al. 1993, Seder \& Gros 1995, Paganelli et al 1995, Del Prete et al. 1995). Helper T cell activity, for the induction of B cell activation/differentiation and Ig secretion, involves the secretion of several cytokines, as well as interactions mediated by cell-surface stimulatory molecules, such as CD40-ligand and CD70 (CD27-ligand). These cell-surface molecules are part of a family of TNF-like molecules, which also includes CD30 ligand and fas ligand, which interact with TNF receptor-like molecules on B cells, such as CD40, CD27, and CD95'fas'. CD8 cells might be expected to express elevated levels of molecules such as CD40-ligand and CD70, if they exert "type 2"-like helper activity for B cells. In preliminary studies, we have detected: (1) elevated levels of circulating CD8+ cells expressing CD70 or CD40-ligand in HIV+ subjects with low CD4 cell number, (2) elevated expression of B7.2 on CD8+ cells in HIV+ people with low numbers of CD4 cells, and (3) a positive correlation between CD70+CD8+ cells ("helper" T cell phenotype) and fas+CD19+ cells (activated B cell phenotype) (unpublished observations). This suggests that CD8 T cells, in people with advanced HIV disease, bear markers characteristic of "type 2" helper T cells. Most recently, work has focused on determining if a "type 2" pattern of cytokine production is seen in CD8 cells; preliminary results suggest that production of IL10 and IFNg, by CD8+ T cells from HIV+ subjects with advanced disease, was elevated (not shown). Together, these results raise the possibility that the inappropriate expression of stimulatory molecules, either on CD8 cells or on B cells, might function to induce $B$ cell hyperactivation and/or promote lymphoma cell growth.

Finally, we have seen that AIDS-lymphoma cell lines express CD40-ligand, CD40, B7.1, B7.2, and $\mathrm{CD} 28$, as well as various other stimulatory molecules, including CD27 and CD70. Since several $\mathrm{B}: \mathrm{T}$ cell ligand:receptor pairs are co-expressed simultaneously on AIDS-lymphoma cells, as well as on circulating B cells in HIV infection, these molecules could potentially be acting in an autostimulatory manner, thereby driving B cell hyperactivation and/or lymphoma cell growth. These possibilities will be considered in future studies.

\section{ACKNOWLEDGMENTS}

To Ben Bonavida, Roger Detels, John Fahey, Min Liu, Tadamitsu Kishimoto, John Oishi, Susan Plaeger, Jonathan Said, Sei Takeshida, Jeremy Taylor, Donna Vredevoe, and Sigal Yawetz, for their contributions to the work presented in this review.

\section{REFERENCES}

Alderson MR, Armitage RJ, Tough TW, Strockbine L, Fanslow WC, Spriggs MK 1993. CD40 expression by human monocytes: regulation by cytokines and activation by the ligand for CD40. J Exp Med 178: 669-674.

Amadori A, Zamarchi R, Ciminale V, Del Mistro A, Siervo S, Alberti A, Colombatti M, Chieco-Bianchi L 1989. HIV-1-specific B-cell activation: a major constitutent of spontaneous B cell activation during HIV-1 infection. J Immunol 143: 2146-2152.

Amadori A, Zamarchi R, Veronese ML, Panozzo M, Barelli A, Borri A, Sironi M, Colotta F, Mantovani A, Chieco-Bianchi L 1991. B cell activation during HIV-1 infection. II. Cell-to-cell interactions and cytokine requirement. J Immunol 146: 57-62.

Armitage RJ, Tough TW, Macduff BM, Fanslow WC, Spriggs MK, Ramsdell F, Alderson MR 1993. CD40 ligand is a T cell growth factor. Eur J Immunol 23: 2326-2331.

Ballerini P, Gaidano G, Gong JZ, Tassi V, Saglio G, Knowles DM, Dalla-Favera R 1993. Multiple genetic lesons in acquired immunodeficiency syndrome-related non-Hodgkin's lymphoma. Blood 81: 166-176.

Beral V, Peterman T, Berkelman R, Jaffe H 1991. AIDS non-Hodgkin lymphoma. Lancet 337: 805-809.

Berberian L, Goodglick L, Kipps TJ, Braun J 1993. Immunoglobulin $\mathrm{VH} 3$ gene products: natural ligands for HIV gp120. Science 261: 1588-1591.

Berberian L, Valles-Ayoub Y, Sun N, Martínez-Maza O, Braun J 1991. A VH clonal deficit in HIV-positive individuals reflects a B cell maturational arrest. Blood 78: 175-179.

Birx DL, Redfield RR, Tosato G 1986. Defective regulation of EBV infection in patients with Acquired Immunodeficiency Syndrome (AIDS) or AIDS-related disorders. New Engl J Med 314: 874-879.

Birx DL, Redfield RR, Tencer K, Fowler A, Burke DS, Tosato G 1990. Induction of interleukin-6 during human immunodeficiency virus infection. Blood 76: 2303-2310.

Blackbourn DJ, Amroziak J, Lennette E, Adams M, Ramachandran B, Levy JA 1997. Infectious human herpesvirus 8 in a healthy North American blood donor. Lancet 349: 609-611.

Breen EC, Rezai AR, Nakajima K, Beall GN, Mitsuyasu RT, Hirano T, Kishimoto T, Martínez-Maza O 1990. Infection with HIV is associated with elevated IL6 
levels and production. J Immunol 144: 480-484.

Burdin N, Rousset F, Banchereau J 1997. B-cell-derived IL-10: production and function. Methods 11: 98111.

Cesarman E, Chang Y, Moore PS, Said JW, Knowles DM 1995. Kaposi's sarcoma-associated herpesviruslike DNA sequences in AIDS-related body-cavitybased lymphomas. New Eng J Med 332: 1186-1191.

Chang Y, Cesarman E, Pessin MS, Lee F, Culpepper J, Knowles DM, Moore PS 1994. Identification of herpesvirus-like DNA sequences in AIDS-associated Kaposi's sarcoma. Science 266: 1865-1869.

Chirmule N, Kalyanaraman VS, Lederman S, Oyaizu N, Yagura H, Yellin MJ, Chess L, Pahwa S 1993. HIV-gp160-induced T cell-dependent B cell differentiation. Role of T cell-B cell activation molecule and IL6. J Immunol 150: 2478-2486.

Clouse KA, Cosentino LM, Weih KA, Pyle SW, Robbins PB, Hochstein HD, Natarajan V, Farrar WL 1991. HIV gp120 env protein has the intrinsic capacity to stimulate monokine secretion. J Immunol 147: 28922901.

de Wit R, Raasveld MH, ten Berge RJ, van der Wouw PA, Bakker PJ, Veenhof CH 1991. Interleukin-6 concentrations in the serum of patients with AIDS-associated Kaposi's sarcoma during treatment with interferon-alpha. J Internal Med 229: 539-542.

Del Prete G, Maggi E, Pizzolo G, Romagnani S 1995. CD30, TH2 cytokines and HIV infection: a complex and fascinating link. Immunol Today 16: 7680.

Edelman AS, Zolla-Pasner S 1989. AIDS: a syndrome of immune dysregulation, dysfunction, and deficiency. FASEB J 3: 22-30.

Emilie D, Coumbaras J, Raphael M, Devergne O, Delecluse HJ, Gisselbrecht C, Michiels JF, Van Damme J, Taga T, Kishimoto T, Crevon MC, Galanaud P 1992. IL-6 production in high-grade B lymphomas: correlation with the presence of malignant immunoblasts in acquired immunodeficiency syndrome and in human immunodeficiency virusseronegative patients. Blood 80: 498-504.

Emilie D, Touitou R, Raphael M, Peuchmaur M, Devergnee O, Rea D, Coumbraras J, Crevon M-C, Edelman L, Job I, Galanaud P 1992b. In vivo production of interleukin-10 by malignant cells in AIDS lymphoma. Eur J Immunol 22: 2937-2942.

Emilie D, Zou W, Fior R, Llorente L, Durandy A, Crevon MC, Maillot MC, Durand-Gasselin I, Raphael M, Peuchmaur M, Galamaud P 1997. Production and IL-6, IL-10, and IL-13 in B-lymphocyte malignancies and in B-lymphocyte hyperactivity of HIV infection and autoimmunity. Methods 11: 133-142.

Endo TA, Masuhara M, Yokouchi M, Suzuki R, Sakamoto H, Mitsui K, Matsumoto A, Tanimura S, Ohtsubo M, Misawa H, Miyazaki T, Leonor N, Taniguchi T, Fujita T, Kanakura Y, Komiya S, Yoshimura A 1997. A new protein containing an SH2 domain that inhibits JAK kinases. Nature 387: 921924.

Erard F, Wild MT, Garcia-Sanz JA, Le Gros G 1993. Switch of CD8 T cells to noncytolytic CD8-CD4- cells that make TH 2 cytokines and help B cells. Science 260: 1802-1805.

Gaidano G, Pastore C, Capello D, Migliazza A, Gloghini A, Saglio G, Carbone A, Dalla-Favera R 1997. Involvement of the bcl-6 gene in AIDS-related lymphomas. Ann Oncol 8: 105-108.

Gail MH, Pluda JM, Rabkin CS, Biggar RJ, Goedert JJ, Horm JW, Sondik EJ, Yarchoan R, Broder S 1991. Projections of the incidence of non-Hodgkin's lymphoma related to AIDS. J Natl Can Inst 83: 695701.

Gearing DP, Comeau MR, Friend DJ, Gimple SD, Thut CJ, McGourty J, Brasher KK, King JA, Gillis S, Mosley B, Ziegler SF, Cosman D 1992. The IL6 signal transducer, gp130: an oncostatin $\mathrm{M}$ receptor and affinity converter for the LIF receptor. Science 255 : 1434-1437.

Hirano T, Akira S, Kishimoto T 1990. Biological and clinical aspects of IL6. Immunol Today 11: 443-449.

Hirano T, Taga T, Yasukawa K, Nakajima K, Nakano N, Takatsuki F, Shimizu M, Murashima A, Tsunasawa S, Sakiyama F, Kishimoto T 1987. Human B cell differentiation factor defined by an anti-peptide antibody and its possible role in autoantibody production. PNAS 84: 228-231.

Honda M, Kitamura K, Mizutani Y, Oishi M, Arai M, Okura T, Igarahi K, Yasukawa K, Hirano T, Kishimoto T 1991. Quantitative analysis of serum IL6 and its correlation with increased levels of serum IL2R in HIV-induced diseases. J Immunol 145: 4059-4064.

Karp JE, Broder S 1991. AIDS and non-Hodgkin's lymphomas. Cancer Res 51: 4743-4756.

Kishimoto T, Taga T, Akira S 1994. Cytokine signal transduction. Cell 76: 253-262.

Kishimoto T, Akira S, Narazaki M, Taga T 1995. Interleukin-6 family of cytokines and gp130. Blood 86: 1243-1254.

Klein G 1989. Multiple phenotypic consequences of the $\mathrm{Ig} / \mathrm{Myc}$ translocation in B-cell-derived tumors. Genes Chromosomes Cancer 1: 3-8.

Knowles DM 1997. Molecular pathology of acquired immunodeficiency syndrome-related non-Hodgkin's lymphoma. Sem Diag Pathol 14: 67-82.

Knowles DM, Cesarman E 1997. The Kaposi's sarcomaassociated herpesvirus (human herpesvirus-8) in Kaposi's sarcoma, malignant lymphoma, and other diseases. Ann Oncol 8: 123-129.

Lafeuillade I, Poizot-Martin R, Quilichini R, Gastaut JA, Kaplanski S, Farnarier C, Mege JL, Bongrand P 1991. Increased IL6 production is associated with disease progression in HIV infection. AIDS 5: 11391140.

Lane HC, Fauci AS 1985. Immunologic abnormalities in AIDS. Ann Rev Immunol 3: 477-500.

Lane HC, Masur H, Edgar LC, Whalen G, Rook AH, Fauci A 1983. Abnormalities of B-cell activation and immunoregulation in patients with AIDS. $N$ Engl $J$ Med 309: 453-458.

Lennette ET, Blackbourn DJ, Levy JA 1996. Antibodies to human herpesvirus type 8 in the general population and in Kaposi's sarcoma patients. Lancet 348: 
858-861.

Liu M, Martínez-Maza O, Johnson MT, Fan J, Kishimoto T, Plaeger-Marshall S 1995. IL-6 induces target cell resistance to HIV-specific cytotoxic lysis. J AIDS Human Retrovirol 9: 321-331.

Lombardi L, Newcomb EW, Dalla-Favera R 1987. Pathogenesis of Burkitt lymphoma: expression of an activated c-myc oncogene causes the tumorigenic conversion of EBV human B lymphoblasts. Cell 49: 161-170.

Macchia D, Almerigogna F, Parronchi P, Ravina A, Maggi E, Romagnani S 1993. Membrane tumor necrosis factor-alpha is involved in the polyclonal Bcell activation induced by $\mathrm{HIV}$-infected human $\mathrm{T}$ cells. Nature 363: 464-466.

Macchia D, Parronchi P, Piccini MP, Simonelli C, Mazzetti M, Ravina A, Milo D, Maggi E, Romagnani $\mathrm{S}$ 1991. In vitro infection with HIV enables human CD4+ T cell clones to induce noncognate contactdependent polyclonal B cell activation. J Immunol 146: 3413-3418.

Macgrath I 1992. Molecular basis of lymphomagenesis. Cancer Res 52: 5529s-5540s.

MacMahon EME, Glass JD, Hayward SD, Mann RB, Becker PS, Charache P, McArthur JC, Ambinder RF 1991. EBV in AIDS-related primary central nervous system lymphoma. Lancet 338: 969-973.

Marfaing-Koka A, Aubin JT, Grangeot-Keros L, Portier A, Benattar C, Merrien D, Agut H, Aucouturier P, Autran B, Wijdenes J 1996. In vivo role of IL-6 on the viral load and on immunological abnormalities of HIV-infected patients. J AIDS Human Retrovirol 11: 59-68.

Martínez-Maza O 1992. IL6 and AIDS. Res Immunol 143: 764-769.

Martínez-Maza O 1993. HIV-induced immune dysfunction and AIDS-associated neoplasms, p. 181-204. In MS Mitchell, Biological Approaches to Cancer Treatment - Biomodulation, McGraw-Hill, New York.

Martínez-Maza O, Crabb E, Mitsuyasu RT, Fahey JL, Giorgi JV 1987. Infection HIV is associated with an in vivo increase in B lymphocyte activation and immaturity. J Immunol 138: 3720-3724.

Matsuda T, Suematsu S, Kawano M, Yoshizaki K, Tang B, Tanabe O, Nakajima T, Akira S, Hirano T, Kishimoto T 1989. IL6 in normal and abnormal regulation of immune responses. Ann NY Acad Sci 557: 466-476

Minamoto S, Ikegame K, Ueno K, Narazaki M, Naka T, Yamamoto H, Matsumoto T, Saito H, Hosoe S, Kishimoto T 1997. Cloning and functional analysis of new members of STAT induced STAT inhibitor (SSI) family: SSI-2 and SSI-3. Biochem Biophys Res Comm 237: 79-83.

Mizuma H, Litwin S, Zolla-Pazner S 1988. B cell activation in HIV infection: relationship of spontaneous immunoglobulin secretion to various immunologic parameters. Clin Exp Immunol 71: 410-416.

Molden J, Chang Y, You Y, Moore PS, Goldsmith MA 1997. A Kaposi's sarcoma-associated herpesvirusencoded cytokine homolog (vIL-6) activates signal- ing through the shared gp130 receptor subunit. J Biol Chem 272: 19625-19631.

Moore PS, Boshoff C, Weiss RA, Chang Y 1996. Molecular mimicry of human cytokine and cytokine response pathway genes by KSHV. Science 274 : 1739-1744.

Moore RD, Kessler H, Richman DD, Flexner C, Chaisson RE 1991. Non-Hodgkin's lymphoma in patients with advanced HIV infection treated with zidovudine. JAMA 265: 2208-2211.

Muñoz A, Schrager LK, Bacellar H, Speizer I, Vermund SH, Detels R, Saah AJ, Kingsley LA, Seminara D, Phair JP 1993. Trends in the incidence of outcomes defining acquired immunodeficiency syndrome (AIDS) in the Multicenter AIDS Cohort Study: 19851991. Am J Epidemiology 137: 423-438.

Naka T, Narazaki M, Hirata M, Matsumoto T, Minamoto S, Aono A, Nishimoto N, Kajita T, Taga T, Yoshizaki K, Akira S, Kishimoto T 1997. Structure and function of a new STAT-induced STAT inhibitor. Nature 387: 924-929.

Nakajima K, Martínez-Maza O, Hirano T, Breen EC, Nishanian PG, Salazar-Gonzalez JF, Fahey JL, Kishimoto T 1989. Induction of IL6 (BSF-2/IFNb 2 ) production by HIV. J Immunol 142: 531-536.

Neri A, Barriga F, Knowles DM, Magrath IT, DallaFavera R 1988. Different regions of the immunoglobulin heavy-chain locus are involved in chromosomal translocations in distinct pathogenetic forms of Burkitt lymphoma. PNAS (USA) 85: 2748-2752.

Nicholas J, Ruvolo V, Zong J, Ciufo D, Guo HG, Reitz MS, Hayward GS 1997. A single 13-kilobase divergent locus in the Kaposi sarcoma-associated herpesvirus (human herpesvirus 8) genome contains nine open reading frames that are homologous to or related to cellular proteins. J Virol 71: 1963-1974.

Neipel F, Albrecht JC, Ensser A, Huang YQ, Li JJ, Friedman-Kien AE, Fleckenstein B 1997. Human herpesvirus 8 encodes a homolog of interleukin-6. $J$ Virol 71: 839-842.

Noelle RJ, Ledbetter JA, Aruffo A 1992. CD40 and its ligand, an essential ligand-receptor pair for thymusdependent B-cell activation. Immunol Today 13: 431433.

Paganelli R, Scala E, Ansotegui IJ, Ausiello CM, Halapi E, Fanales-Belasio E, D’Offizi G, Mezzaroma I, Pandolfi F, Fiorilli M 1995. CD8+ T lymphocytes provide helper activity for IgE synthesis in HIV-infected patients with hyper-IgE. J Exp Med 181: 423428.

Pahwa S, Pahwa R, Saxinger C, Gallo RC, Good RA 1985. Influence of HTLV/LAV on functions of human lymphocytes: evidence for immunosuppressive effects and polyclonal B-cell activation by banded viral preparations. PNAS 82: 8198-8202.

Pahwa S, Pahwa R, Good RA, Gallo RC, Saxinger C 1986. Stimulatory and inhibitory influences of HIV on normal B lymphocytes. PNAS 83: 9124-9128.

Parker DC 1993. T cell-dependent B cell activation. Ann Rev Immunol 11: 331-360.

Pluda JM, Yarchoan R, Jaffe ES, Feuerstein IM, Solomon D, Steinberg SM, Wyvill KM, Raubitschek A, Katz 
D, Broder S 1990. Development of non-Hodgkin Lymphoma in a cohort of patients with severe HIV infection on long-term antiretroviral therapy. Ann Int Med 113: 276-282.

Potter M 1992. Pathogenetic mechanisms in B-cell nonHodgkin's lymphomas. Cancer Res 52: 5522s-5528s.

Przybylski GK, Goldman J, Ng VL, McGrath MS, Herndier BG, Schenkein DP, Monroe JG, Silberstein LE 1996. Evidence for early B-cell activation preceding the development of Epstein-Barr virus-negative acquired immunodeficiency syndrome-related lymphoma. Blood 88: 4620-4629.

Rautonen J, Rautonen N, Martin NL, Philip R, Wara DW 1991. Serum IL6 concentrations are elevated and associated with elevated tumor necrosis factoralpha and immunoglobulin $\mathrm{G}$ and A concentrations in children with HIV infection. AIDS 5: 1319-1325.

Rieckmann P, Poli G, Kehrl JH, Fauci AS 1991. Activated $\mathrm{B}$ lymphocytes from HIV-infected individuals induce virus expression in infected T cells and a promonocytic cell line, U1. J Exp Med 173: 1-5.

Rosenberg ZF, Fauci AS 1990. Immunopathogenic mechanisms of HIV infection: cytokine induction of HIV expression. Immunol Today 11: 176-180.

Roy M, Waldschmidt T, Aruffo A, Ledbetter JA, Noelle RJ 1993. The regulation of the expression of gp39, the CD40 ligand, on normal and cloned CD4+ T cells. J Immunol 151: 2497-2510.

Russo JJ, Bohensky RA, Chien M-C, Chen J, Yan M, Maddelena D, Parry JP, Peruzzi D, Edelman IS, Chang Y, Moore PS 1996. Nucleotide sequence of the Kaposi sarcoma-associated herpesvirus (HHV8). PNAS (USA) 93: 14862-14867.

Schnittman SM, Lane HC, Higgins SE, Folks T, Fauci AS 1986. Direct polyclonal activation of human B lymphocytes by the acquired immune deficiency syndrome virus. Science 233: 1084-1086.

Schulz TF, Boshoff CH, Weiss RA 1996. HIV infection and neoplasia. Lancet 348: 587-591.

Seder RA, Le Gros CG 1995. The functional role of CD8+ T helper type 2 cells. J Exp Med 181: 5-7.

Shevach EM 1993. Accessory Modules, in Fundamental Immunology, 3rd ed., WE Paul, Raven Press, NY, $531 \mathrm{pp}$.

Shiramizu B, Macgrath I 1990. Localization of breakpoints by polymerase chain reactions in Burkitt's lymphoma with 8;14 translocations. Blood
75: 1848-1852.

Starr R, Wilson TA, Viney EM, Murray LJL, Rayner JR, Jenkins BJ, Gonda TJ, Alexander W, Metcalf D, Nicola NA, Hilton DJ 1997. A family of cytokineinducible inhibitors of signaling. Nature 387: 917-921.

Subar M, Neri A, Inghirami G, Knowles DM, DallaFavera R 1988. Frequent c-myc oncogene activation and infrequent presence of EBV genome in AIDS-associated lymphoma. Blood 72: 667-671.

Takeshida S, Breen EC, Ivashchenko M, Rezai AR, Nishanian P, Vredevoe D, Kishimoto T, MartínezMaza O 1995. Induction of IL-6 and IL-10 production by recombinant HIV-1 envelope glycoprotein gp41 in the THP-1 human monocytic cell line. Cell Immunol 165: 234-242.

Tosato G, Blaese RM 1985. EBV infection and immunoregulation in man. Adv Immunol 37: 99-149.

Vincent C, Cozon G, Zittoun M, Mellquist M, Kazatchkine MD, Czerkinsky C, Revillard JP 1992. Secretory immunoglobulins in serum from HIV-infected patients. J Clin Immunol 12: 381-388.

Widney D, Yawetz S, van der Meyden M, Miles SA, Kishimoto T, Martínez-Maza O 1994. Effects of zidovudine on B lymphocyte activation. Cellular Immunol 158: 140-156.

Yarchoan R, Redfield RR, Broder S 1986. Mechanisms of $B$ cell activation in patients with acquired immunodeficiency syndrome and related disorders. Contribution of antibody-producing B cells, of EpsteinBarr virus-infected B cells, and of immunoglobulin production induced by human $\mathrm{T}$ cell lymphotropic virus, type III/lymphadenopathy-associated virus. $J$ Clin Invest 78: 439-447.

Yawetz S, Cumberland WG, van der Meyden M, Martínez-Maza O 1995. Elevated serum levels of soluble CD23 (sCD23) precede the appearance of AIDS-associated non-Hodgkin's lymphoma. Blood 85: 1843-1849.

Ziegler JL 1987. AIDS and cancer. Ann Inst Pasteur Immunol 138: 253-260.

Zinzani PL, Baccini C, Zaccaria A, Visani G, Buzzi M, Morelli A, Molinari AL, Salvucci M, Bendandi M, Rubboli D, Gherlinzoni F, Zanchini R, Tura S 1996. Clinical implications of serum levels of soluble CD23 and tumor necrosis factor alpha in low-grade non-Hodgkin's lymphoma. Eur J Haematol 57: 335340 . 
382 Immune Dysfunction and AIDS-lymphoma - OM-Maza et al. 